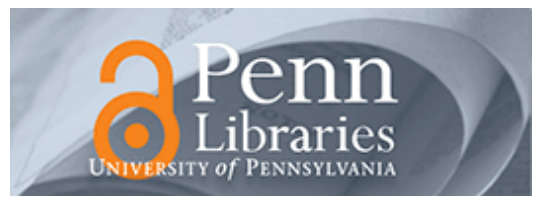

Studies in Visual Communication

Volume 9

Issue 4 Fall 1983

Article 4

1983

\title{
The United States View Company of Richfield, Pennsylvania (Photo Essay)
}

Jay Ruby

\section{Recommended Citation}

Ruby, J. (1983). The United States View Company of Richfield, Pennsylvania (Photo Essay). 9 (4), 45-64.

Retrieved from https://repository.upenn.edu/svc/vol9/iss4/4

This paper is posted at ScholarlyCommons. https://repository.upenn.edu/svc/vol9/iss4/4

For more information, please contact repository@pobox.upenn.edu. 
The United States View Company of Richfield, Pennsylvania (Photo Essay) 


\title{
The United States View Company of Richfield, Pennsylvania (Photo Essay)
}

\author{
Jay Ruby
}

Portraiture has always been the mainstay of photography in America. However, our need to preserve memories has never been confined to people. Rural and small-town America have been particularly proud of their ability to build and own their own homes. The ability to own a home and pride in that ownership separate Americans from other people in the world. It seems only natural, therefore, for Americans to preserve the memory of their homes in the same way that they are able to keep the memory of their family alive - through photography.

By 1890, dry glass plate negatives and sturdy but lightweight cameras with fast lenses made it possible for the traveling photographer to go to the home of the rural dweller and offer to take a view (see Figure 1). It was both a family portrait and a picture of the homestead large enough to be hung on the wall of the family's living room or sent to relatives who lived elsewhere

Like the portrait photographer, the view photogra pher had to compete with the painter for the same market:

To the majority of citizens in the early republic, the ideal American home was an independent homestead attractive enough to encourage family pride yet unpretentious and economical. Itinerant artists, traveling across the countryside on horseback, specialized in paintings that portrayed these very qualities. Such artists decorated the interiors of homes with bright geometric patterns and naive murals and often did a painting of the family dwelling or a portrait of the family members. [Wright 1981:73]

Between 1880 and 1910 hundreds of view companies were formed in the United States. Their operators roamed the countryside with company-outfitted buggies (see Figure 2), taking views of houses. The negatives were shipped back to the company headquarters, where they were developed, printed, and mounted in frames. A few weeks later a salesman would bring the framed view to the family and try to convince them to buy additional copies.

Several men are going through this community and photographing homesteads, schools and most anything you wish to have photographed. ["East Salem Jottings," Port Royal Times, Pa., May 23, 1889]

The photographer, who was in this community some time ago photographing, has delivered the pictures. Some of them present a very fine appearance. ["East Salem Jottings," Port Royal Times, Pa., May 23, 1889]

Jay Ruby is Associate Professor of Anthropology at Temple University and Co-Editor of Studies in Visual Communication.
We will probably never know just how many view companies were in business since they were most often small enterprises lasting only a few years, owned by people usually engaged in other activities. Salesmen and operators sometimes worked only parttime in the summers. The views themselves, having lost their original meaning, turn up at country auctions valued only as "picture frames." They have not been considered worthy of the attention of most scholars and, like cabinet card photographs, represent an invisible part of the history of photography

In the process of researching a history of photography in Juniata County, Pennsylvania (Ruby 1981), I discovered the remnants of the United States View Company of Richfield, Pa. With the kind permission of Mrs. Martha Graybill, the daughter-in-law of one of the company's late owners, I was able to examine the workings of one company.

In the towns of Richfield, Pa., and its Snyder County neighbor, Mount Pleasant Mills, five different view companies were operating-The U.S. View, Acme View, National View, and Excelsior View-all probably owned by the same people. In addition, there was the American View Company, which later became known as the American Photo Company. It is slightly incredible that in two tiny hamlets, with a combined population of less than one thousand, so many view companies were able to exist. It gives some indi cation of how popular these pictures must have been

The United States View Company was formed by Henry and Newton Graybill and Ellsworth Garman sometime in the late 1880 s or early 1890 s. The Graybill brothers were in partnership with Garman in a general store in Richfield. Newton Graybill probably learned how to run a view company while working for the Keystone View company (owned by F. L. Landon, 629 Hamilton Street, Allentown, Pa.), and from J. R. Fisher, Mount Pleasant Mills Carte de Visite photographer.

Two sources of information remain to tell us something about the activities of the U.S. View Company: about 400 photographs and Newton Graybill's notebook, which contains instructions to his operators and salesman. They provide a remarkable and rare insight into the workings of a view company. 
Here are excerpts from Mr. Graybill's notebook:

\section{INSTRUCTIONS TO OPERATORS:}

When first you approach a gentleman or lady, address them with a reasonable amount of politeness and proceed to make your business known at once. Do not act as though you were waiting for their advice. Just say: "I'm going to make a picture of your place for my own use if you do not object."

He or she may ask numerous questions on this point. All you have to do is to assure them, and all this time be making progress toward taking the picture. That is, be looking the place over as though to get the best position while talking, and in an unconcerned way, say: "Did anyone ever make a picture of it?" This will let you know if they ever had it photographed or not. If they have, ask to see it. If it is as good as we can make, do not photograph it. If the picture they have is small and poor and they are willing to let you photograph the place, you may do so.

If the one they have is good, the best way to get out of it is to make a blank exposure and say: "Much obliged for troubling you. Good bye."

When you have decided to make a picture, say to them: "It would improve the picture to have all the family in sight." Don't say this in a persuading manner, but as though it was to their option to stand out or not.

HOW THINGS SHOULD BE ARRANGED:

While the family is preparing themselves for the picture, the operator should place the camera in position. See that the window shutters are open, or if the windows are nicely curtained inside, raise some of the windows so that the curtains will show. Place some chairs on the porch or in the yard to make it appear as though the family was setting out. Rocking chairs with ladies always look good on the porch.

By the time the family is ready, you will have all this done. Place the group as near the centre of the picture as possible. The heads of the family in the best place to be seen. Never sit or stand them all in a row. Some sit, some stand. Some lean against the fence or some other suitable place. Have all hats, bonnets and white aprons taken off, and do not have the men photographed with coats off; shirt sleeves and old clothes show bad taste to the operator. See that there are no strangers and hired help in the group before exposing the plate. Always place strangers and hired help so far to one side of the picture that they don't take.

Place the group about one third of the way from the house to the camera as a rule. Be sure that everything is focused sharp. Make the exposure as short as possible. Never have your hand on camera or tripod while making exposure.

When you take names, always take the given name in full as he or she are commonly called. Take the name and number of the slide, give them a hand bill and show them a sample picture with a little explanation, such as price, when it will be delivered, and when they will see it, etc. Always be polite and manly, but have a little dignity and business in your movements.

Subjects that you shall photograph at my risk: Farm and town houses; views of houses and barns; barns and stock; family groups; mills; factories of all kinds; school groups; railroad groups; groups of laboring men whenever they will allow you to arrange them in a proper way to photograph.

Subjects that you must not photograph unless ordered: Interiors; rented houses; houses they have pictures of; houses under construction, not complete whether new or rebuilding; houses where the people will not stand out, where the people will not put on a coat or take off their hats; views of mountains, valleys, ravines, bridges, waterfalls, rocks, rivers; old mills and water wheels not in use; graveyards, monuments, churches; fancy stock such as stallions, bulls, dogs, cats, chickens, hogs, sheep and pets of all kinds.

Never expose a plate on anything outside of our regular work until you have given them to understand that it will cost $\$ 1.50$ no matter how small or how few. You may make cabinet negatives if they are asked for and you are sure you can make them well. Be careful to have them understand the price before taking, which is:

Half-dozen $\$ 2.00$, one dozen $-\$ 3.00$, two dozen- $\$ 5.00$. Take all the old pictures you can to copy and enlarge. Sales are to be made by the salesman. Operators are only expected to make salable views.

Never expose the plate until the family or all that can be gotten are in the group. Many times you will find it necessary to go to the further side of the farm, blacksmith shop, grocery, or school house to get someone of the family in order to get the group together. This is a very important thing and should be carefully looked after always.

Put up for dinner and over night with the farmers. Never put up at a hotel if you can help it. Always give due bills and never pay cash if you can help it. In giving due bills, never ask a man if he will take a due bill for his pay, but say: "How much is my bill? Well, I'll just give you a due bill for the amount as that is the way we do. Then when the picture is brought, just present the due bill and if you do not buy the picture, the due bill is good for the cash and the man that delivers the picture will pay you for it."

While you are saying this, be writing a due bill on the back of a hand bill and hand it to him without hesitation. If he won't accept it, you can pay him cash. Never put up at a place more than once, as it is in a new place you will secure a sale.

By closely following these directions, you will very greatly oblige

Yours very respectfuly, Newton S. Graybill

He was equally clear about how his salesmen were to conduct themselves:

\section{INSTRUCTIONS TO SALESMEN:}

When you first approach a lady or gentleman, introduce yourself by saying: "I am one of the Keystone View Company, and have a picture of your place I would like to show you if you spare me a few moments to look at it, which will not cost you anything." Never show it without a frame; the frame and glass must be well cleared so as to be tasty in every respect.

Also look the same yourself. Be polite and gentlemanly and carry an air of dignity and business. When you meet 
a man that has a title, address him as such. Act as though you had something that was valuable and choice

Always be with the picture until it is sold, then leave as soon as possible. Never leave the picture to be criticised in your absence. Never allow them to take the picture and talk it over by themselves. Follow them up and be in as much of a hurry as would be reasonable.

No matter how poor the picture may be, find some good point in it and call their attention to that. Always ask the highest price first. Have them understand that the pic ture is of value whether they buy it or not. Do not act as though if you would not sell it that it would ruin the company, but say: "All right, much obliged for troubling you. If at any time you want the picture, write to headquarters for it."

If you happen to have an extra copy along, hold it at its value as much as the others. Don't throw it in as though it was worthless. Always sell the picture you have with you before you ask for reprints, and get your pay. Then try reprints at the reduced price.

Prices to sell by: One-\$1.50, two $\$ 2.50$, three$\$ 3.00$, six - $\$ 5.00$, twelve- $\$ 9.00$. After twelve sold, 50 cents each.

Prices of frames: $10 \times 12-\$ 1.25,10 \times 12-75 \not$.

If the surviving views are any indication, the instructions were followed by Mr. Graybill's operators. Well over $75 \%$ of the photographs are houses with the family standing in front, hats and aprons off. Figure 3 , a view of Mr. and Mrs. Newton Graybill and son Seward in front of their house, can undoubtedly be examined as a view exemplar of the style; after all, an operator does not take a view of the boss' house without great thought.

The photographs show a range of people who wished to preserve their lives. The well-to-do (see Figure 4) and people of extremely modest means (see Figure 5) were photographed, along with smalltown dwellers (see Figure 6) and farmers (see Figure 7).

Not all the surviving views are marked as to the name and locale of the customer. Those images which are identified are all from Pennsylvania. Only one view shows a black family (see Figure 8 ). The need to have the entire family in the picture sometimes made it necessary to represent missing members symbolically by including a photograph of them in the view (see Figure 9).

In addition to covering their major market-views of people and their homes-the U.S. View Co. operators took other pictures. They recorded men at work-railroaders (see Figure 10); ship workers (or possibly owners; see Figure 11); stores and their employees (see Figure 12); and even hotels (see Figure 13). One is reminded here of Neal Slavin's book, When Two or More Are Gathered Together (1976). The view which deviates the most from Mr. Graybill's admonitions is a photograph of a funeral wreath for a B\&O Railroad employee (see Figure 14).
Most people assumed the stiff pose of the photographer's studio. Occasionally, an operator produced an informal family grouping such as the one seen in Figure 15. The intent of some images is lost forever. We can only ponder at the reason why the women in Figure 16 placed their spinning wheels in the middle of a field or the reason why the group in Figure 17 sought to be photographed as they were.

View companies appear to have lost their appeal rapidly; most were gone by the beginning of World War I. Newton Graybill left his partnership with his brother and Ellsworth Garman and formed his own store in 1901. Probably the U.S. View Company was disbanded at that time.

The other Richfield organization, the American View Company, was started by William and Ott Basom. William moved to Charlotte, N.C., in 1899 and then to Oklahoma and Texas, forming branches of the company. Ott stayed in Richfield and continued to operate the company until the 1920s. The Basom brothers made the transition from a view company that took primarily pictures of homes to the American Photo Company, which produced postcard-size photographs of people, homes, and events. Operators now traveled in automobiles instead of buggies (see Figure 18), and the photos were sent directly to the customers through the mail.

By the end of World War I the view photographer found a new means of transportation and a different way to picture homes and farms. He became an aerial photographer who flew over rural communities instead of driving through in a buggy. Joyce DeWolf-North, the daughter of Henry DeWolf, one of the pioneers of aerial views of Pennsylvania, explains:

My father began the business in 1927 and flew in a biplane to take the pictures. His "seatbelt" consisted of tying a rope around his ankle and attaching the other end to the seat. He got into the business when a friend of his who was a pilot took pictures around Rochester and then gave the photos to my father. Being a natural salesman he was not one to let an opportunity go by. The rest of course is history. He originally took orders to have the photos taken but now we do them on speculation only, taking all the photos first and then selling them.

Since the founding of the United States, rural Americans have memorialized their loved ones and their most prized possession, their home. The technology changed from brush and canvas to camera; the horse-and-buggy was replaced by the airplane; but the need for these images has remained constant. 


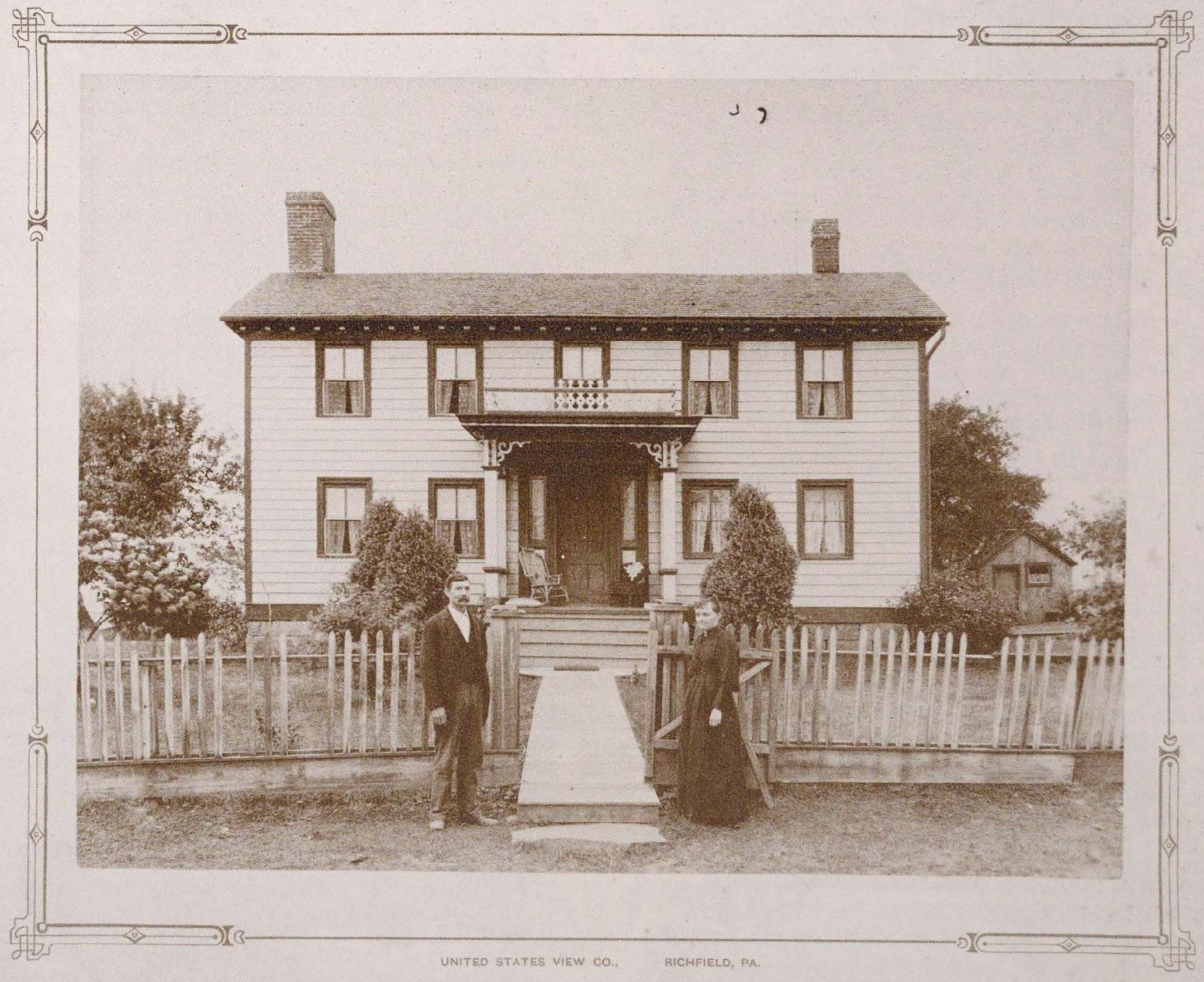

Note: Unless otherwise stated, the view photographs were 8 $\times 10$ inches on a $10 \times 12$ inch mount. Figures 1 through 17 are used with the permission of Martha Graybill; Figure 18 , with the permission of Celo Leitzel.
Figure 1 Unidentified couple. U.S. View Company. 


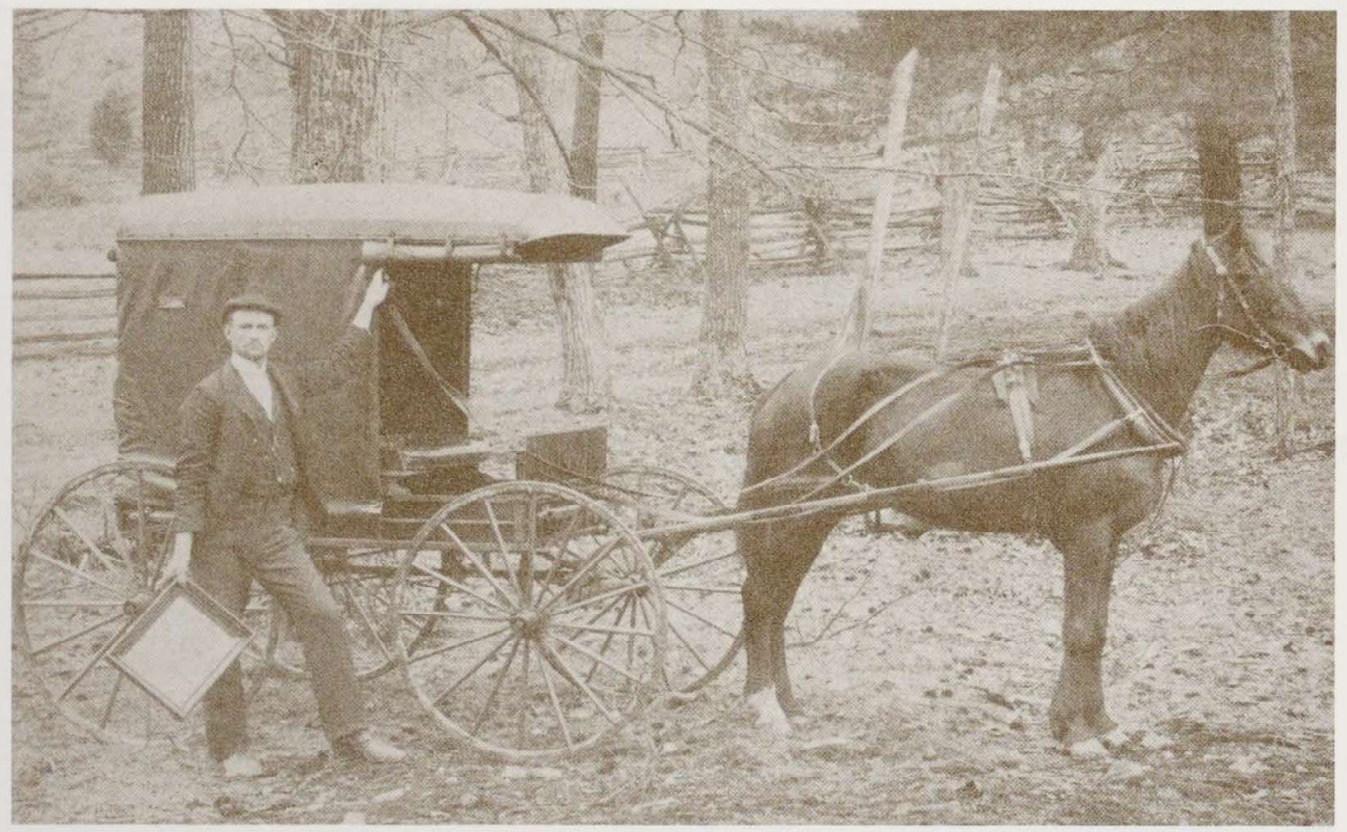

Figure 2 Unidentified. Harry Haas, U.S. View Company operator. 


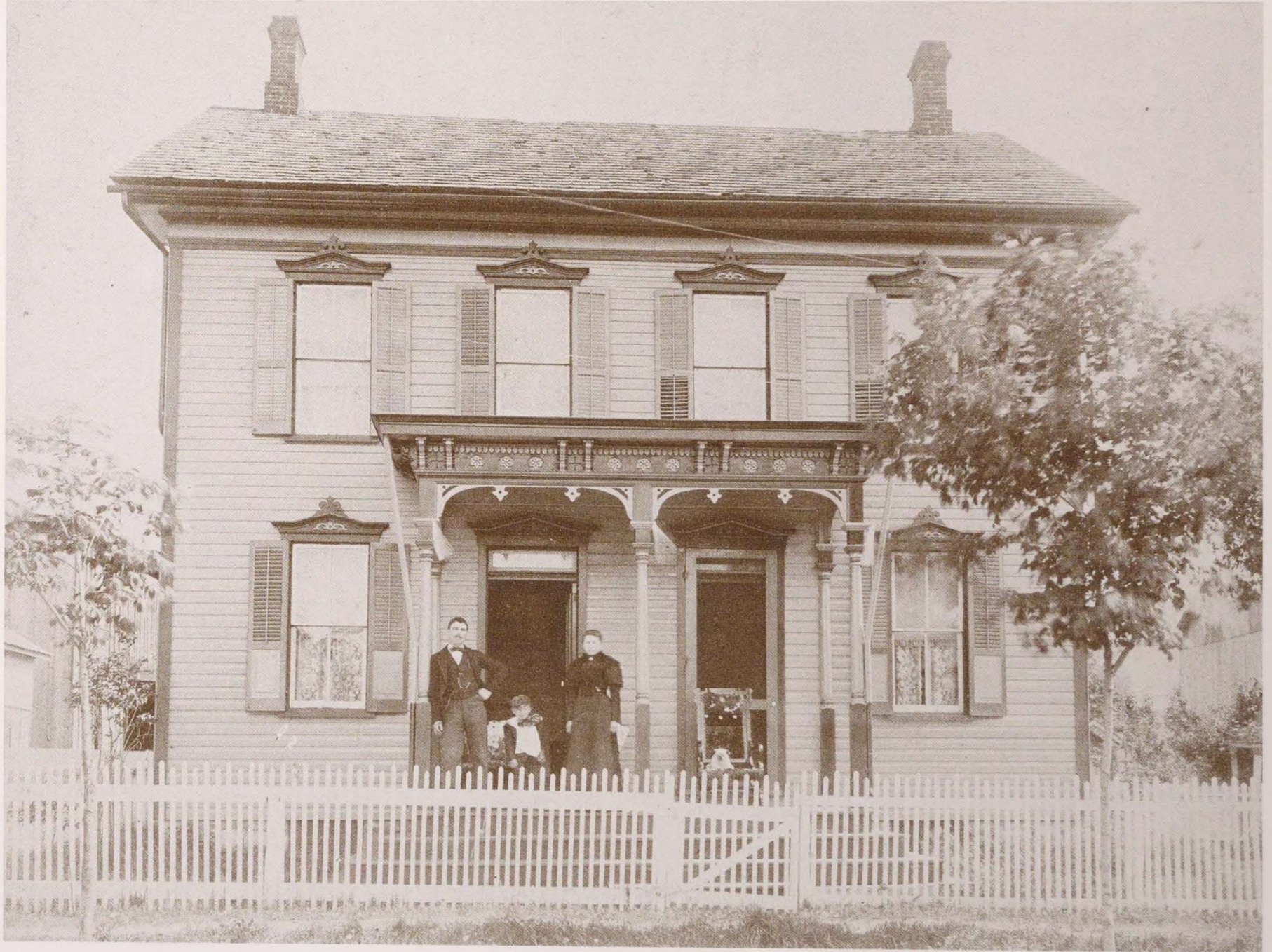

Figure 3 Mr. and Mrs. Newton S. Graybill and Seward. 


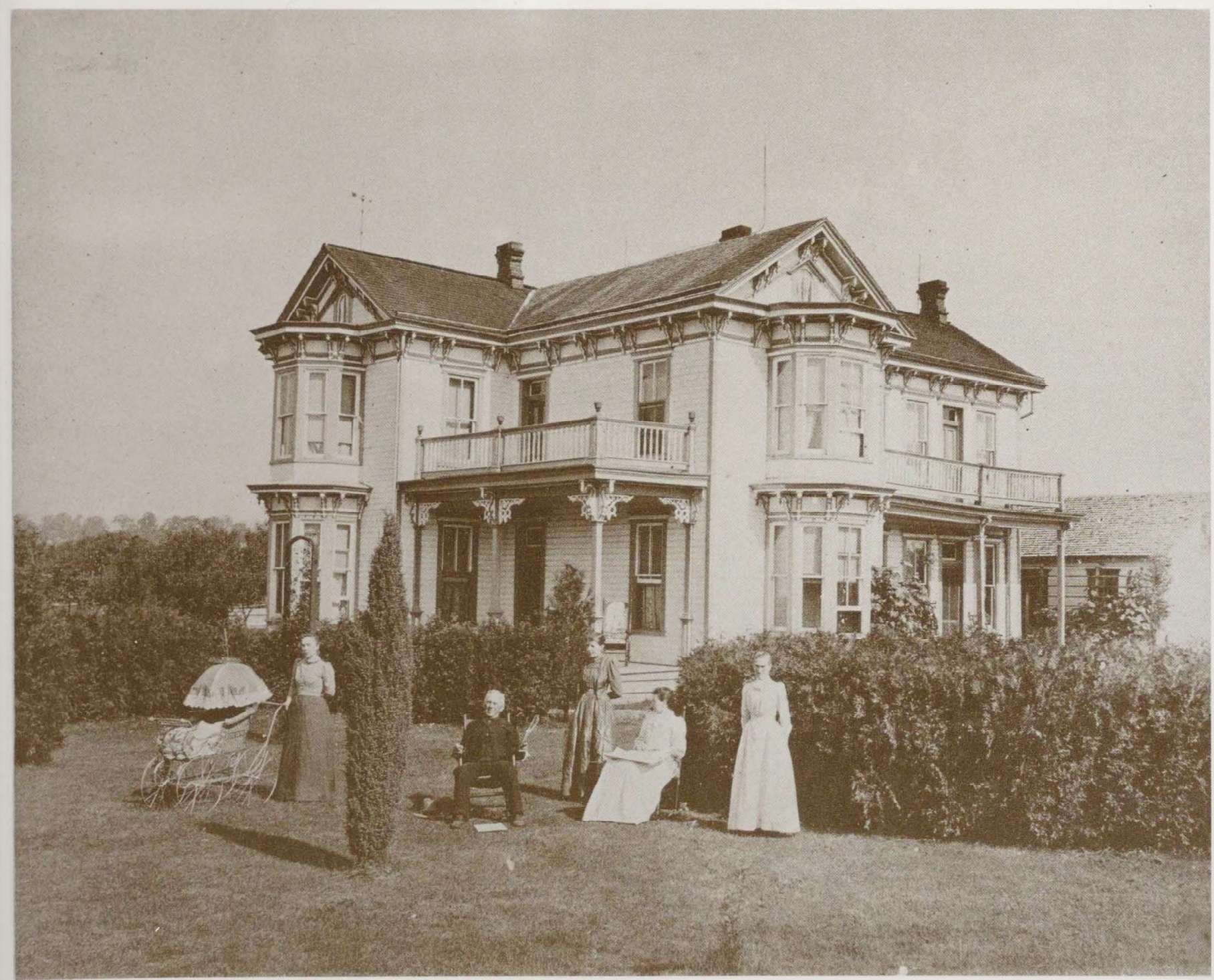

Figure 4 Unidentified family. U.S. View Company. 


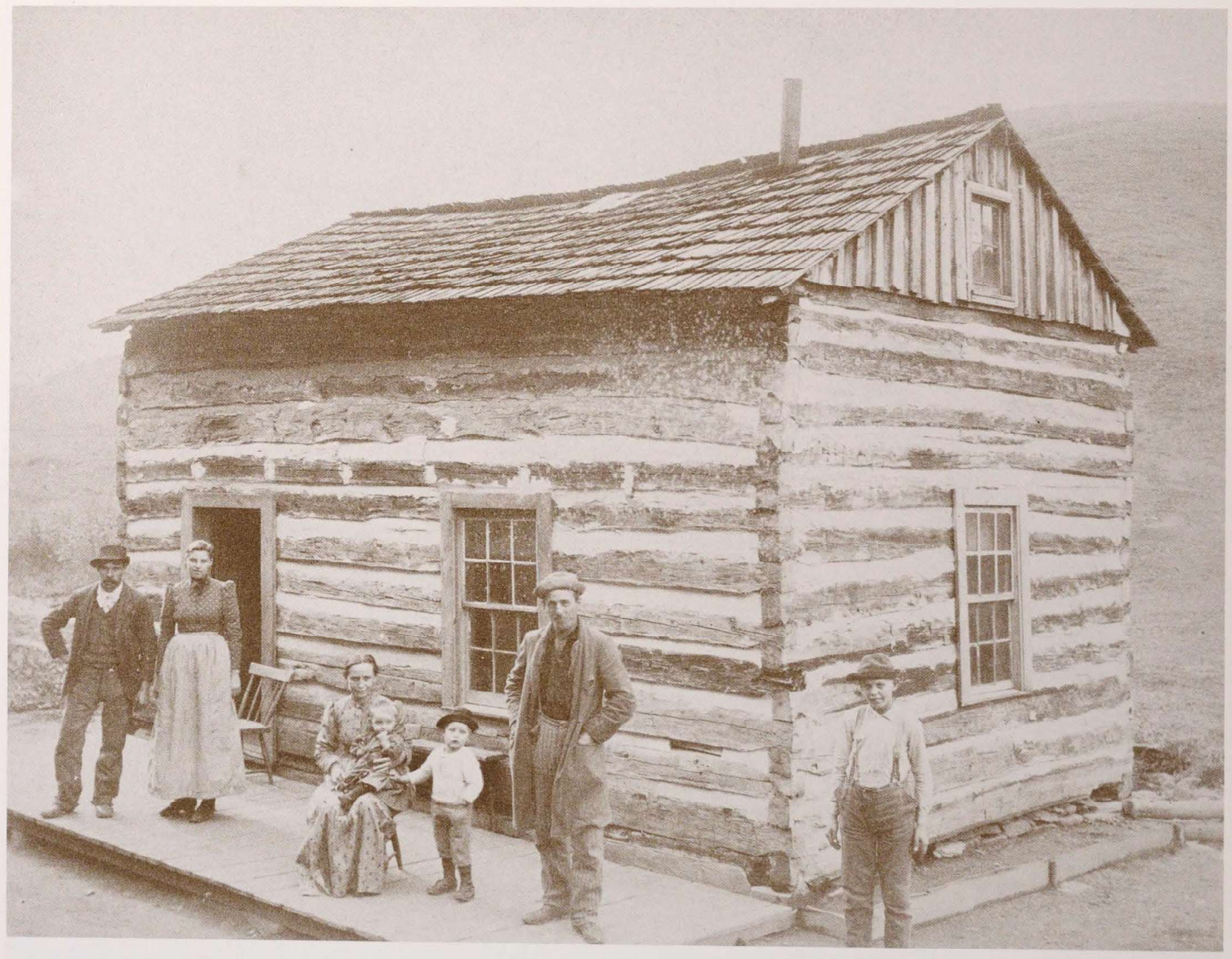

Figure 5 Unidentified family. U.S. View Company. 


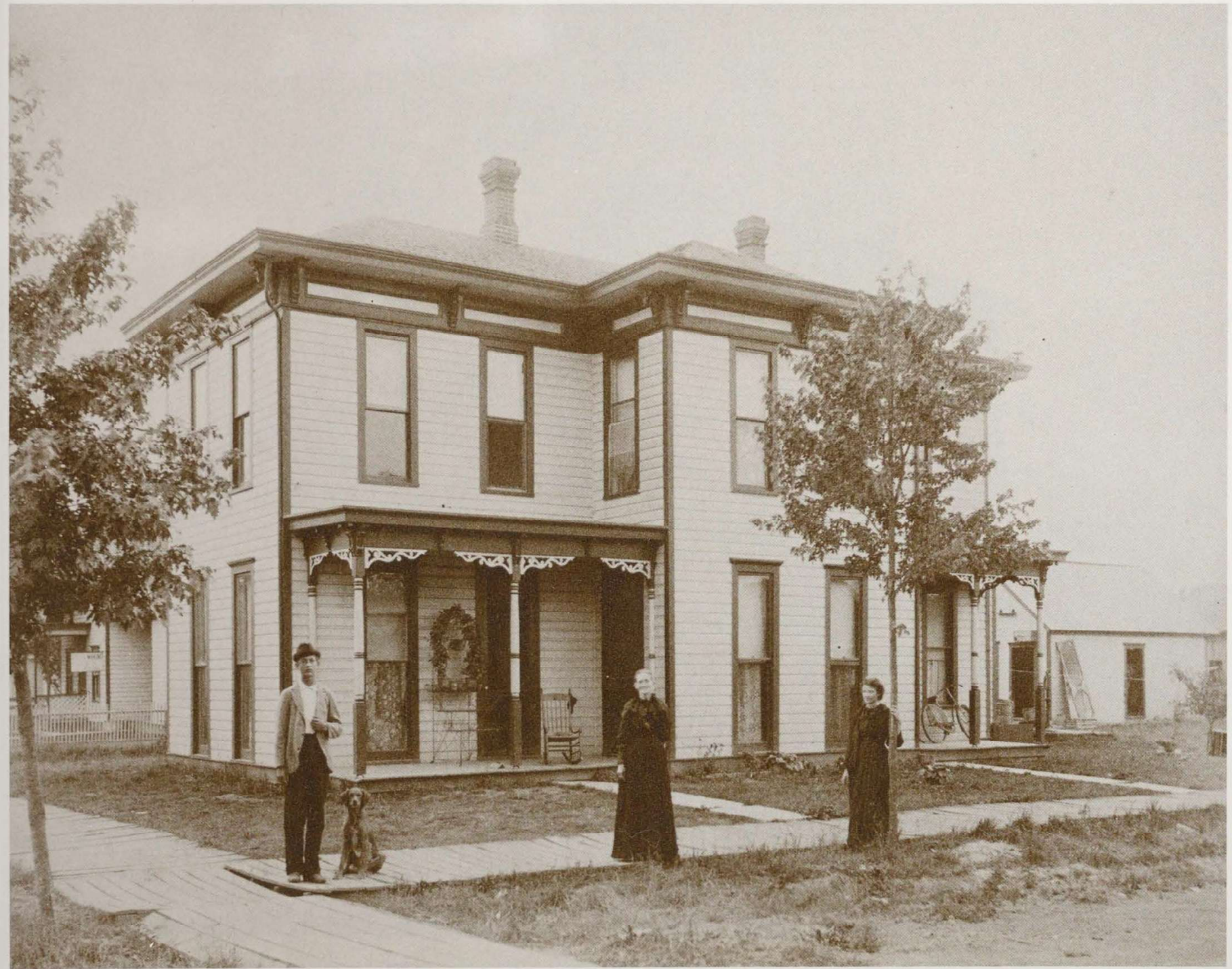

Figure 6 Unidentified family. U.S. View Company. 


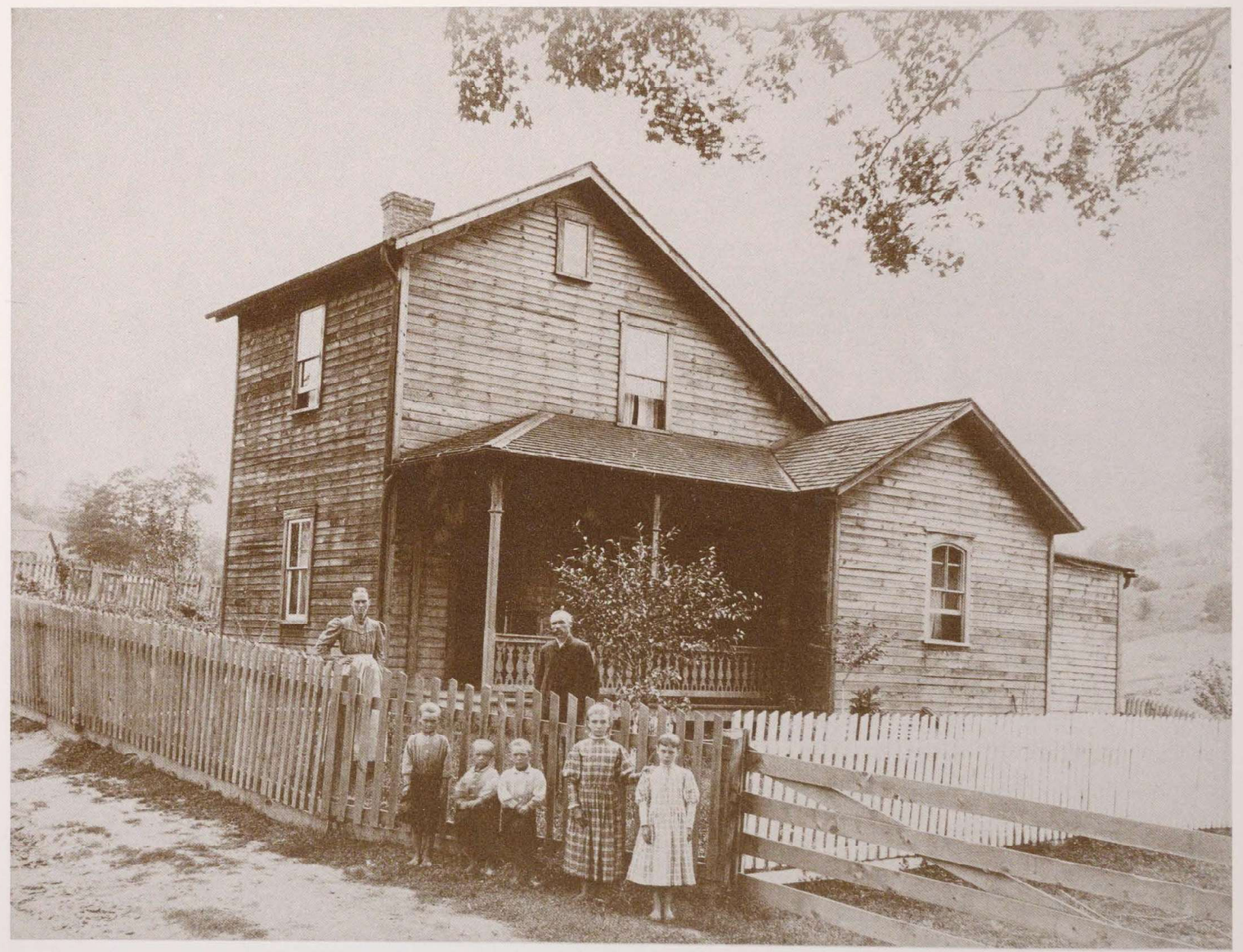

Figure 7 Unidentified family. U.S. View Company. 

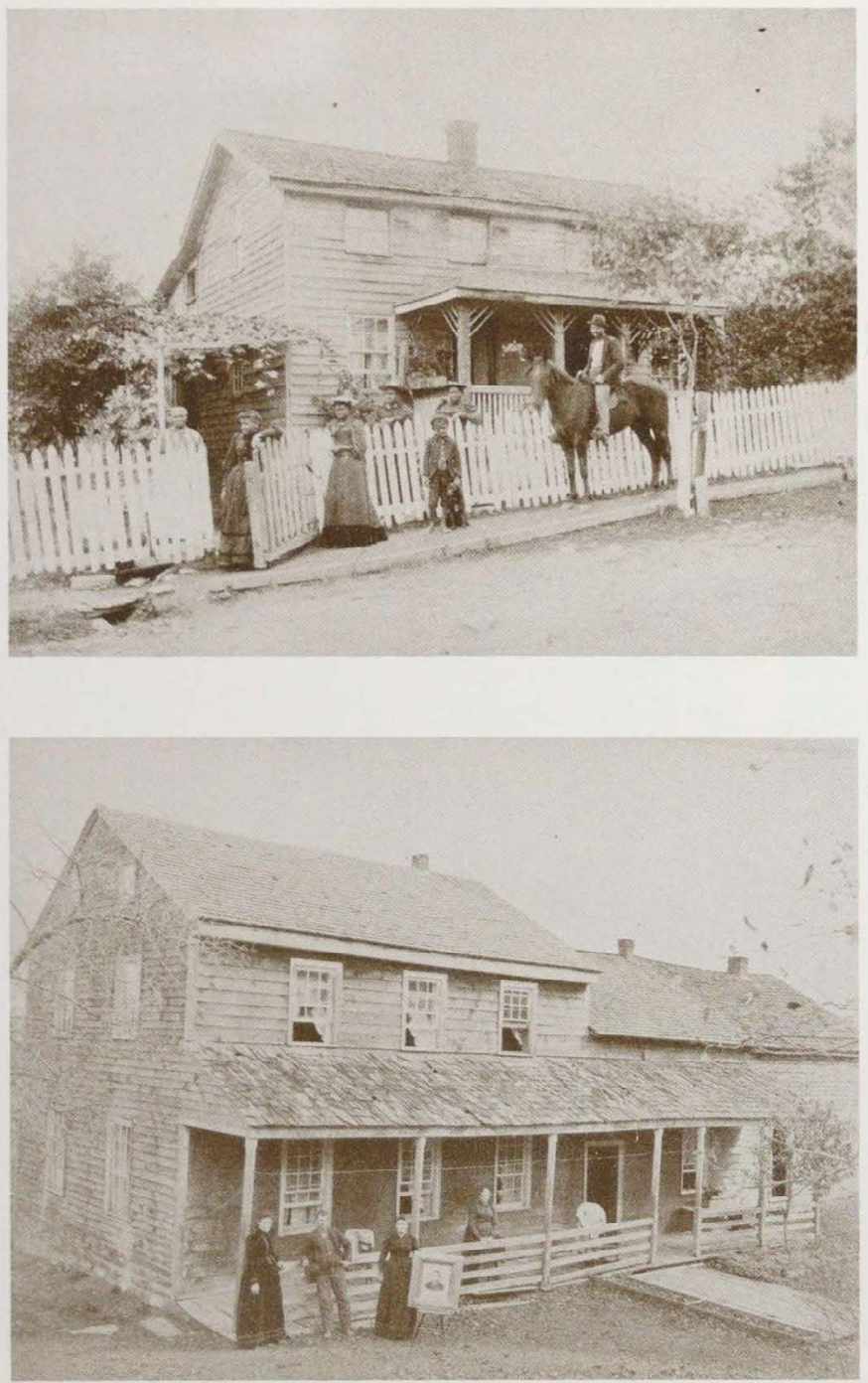

Figure 8 Unidentified family. U.S. View Company.

Figure 9 The Jacob Miller family, Reitz, Pa. U.S. View Company. 


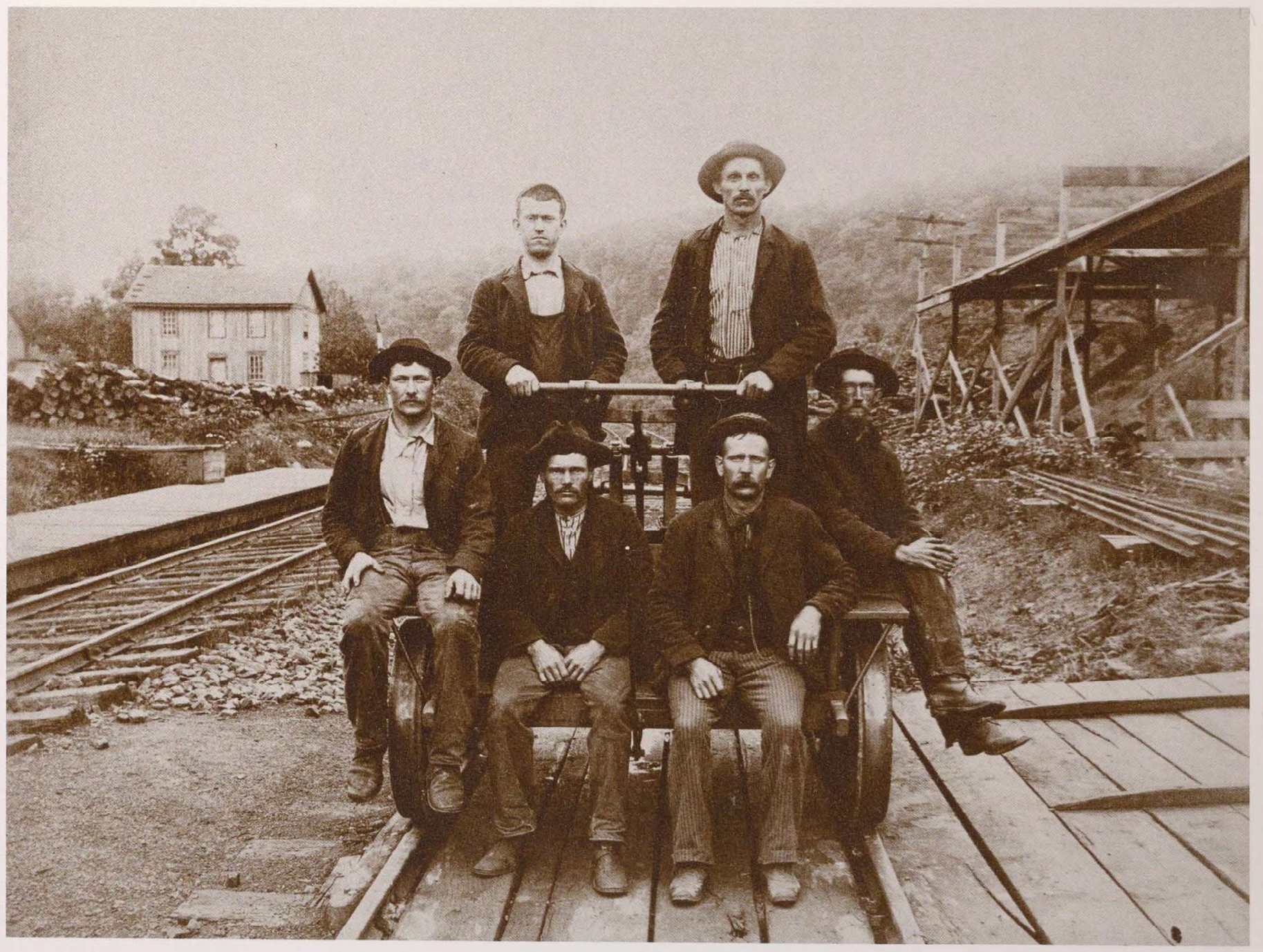

Figure 10 Unidentified group. U.S. View Company. 


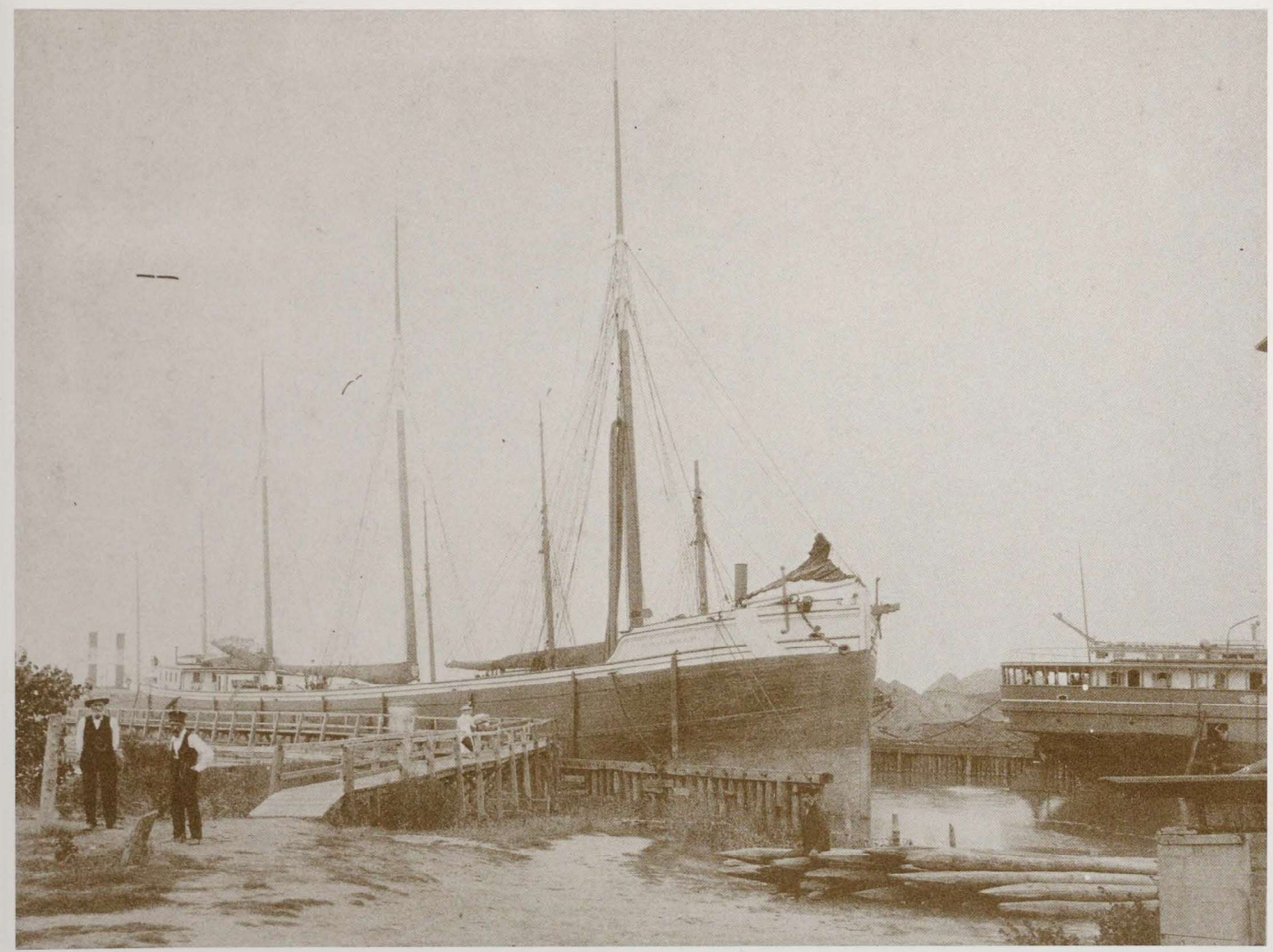

Figure 11 U.S.S. Parker. U.S. View Company. 


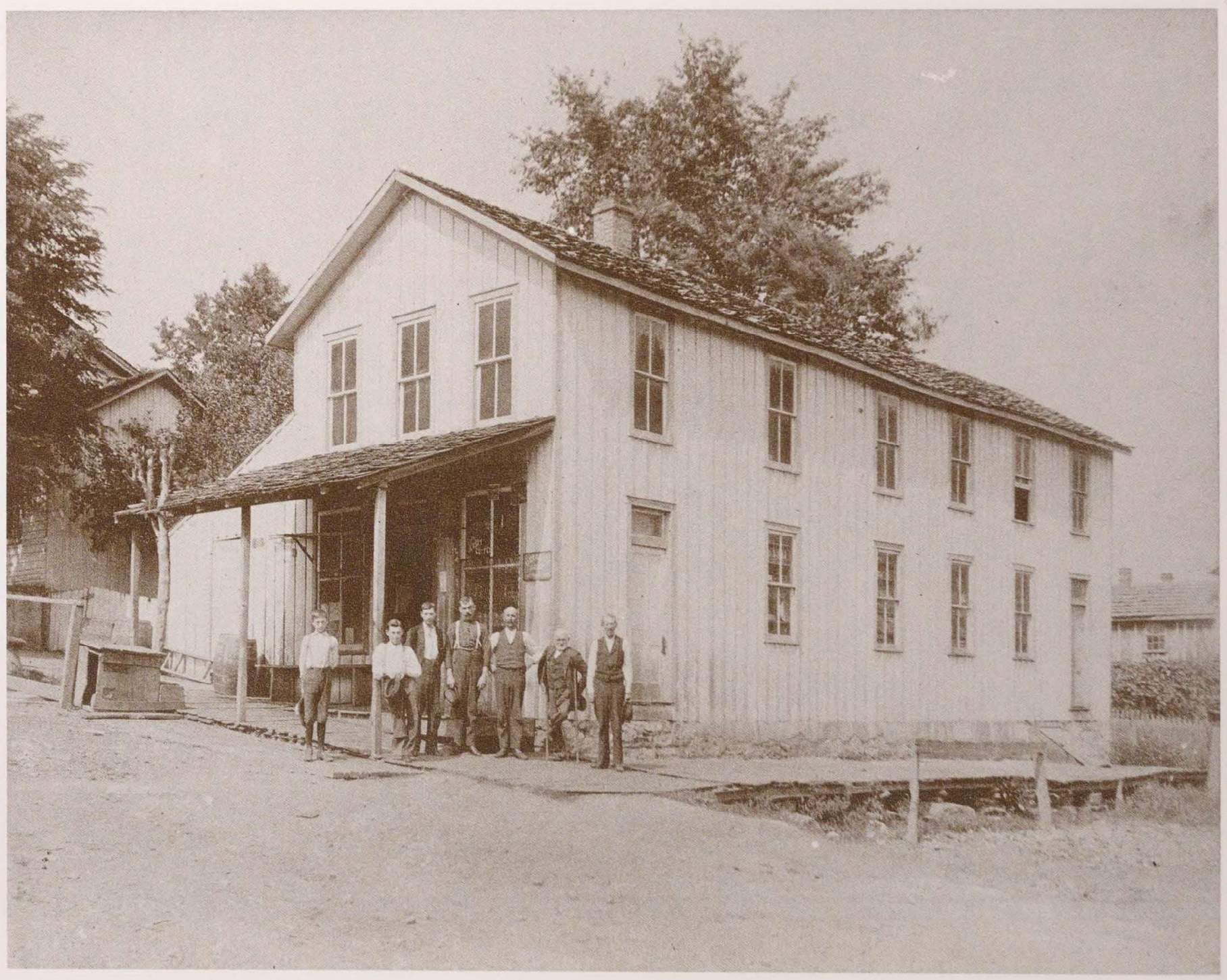

Figure 12 Unidentified group. U.S. View Company. 


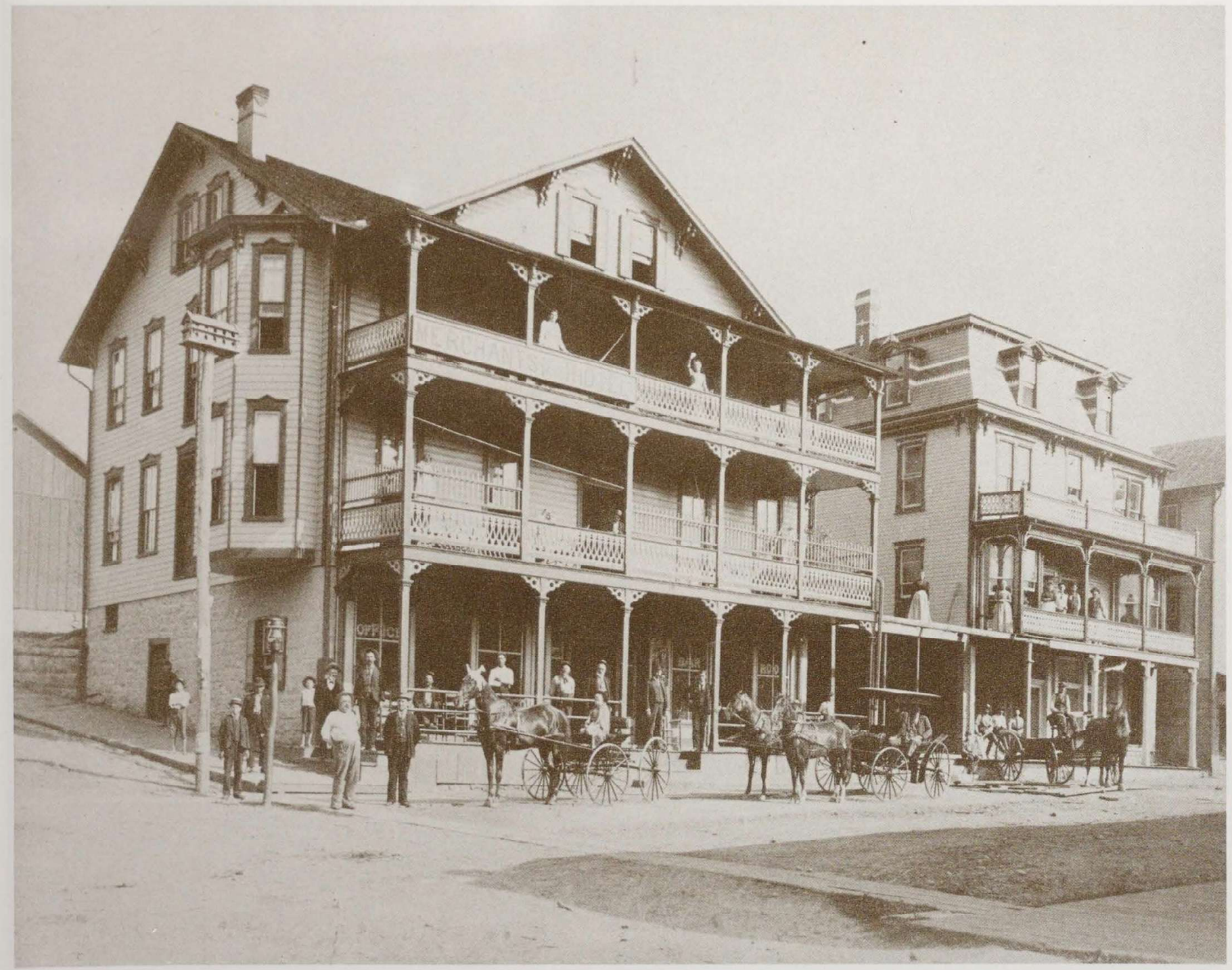

Figure 13 Merchants Hotel, Perock Woods, Somerset County, Pa. U.S. View Company. 


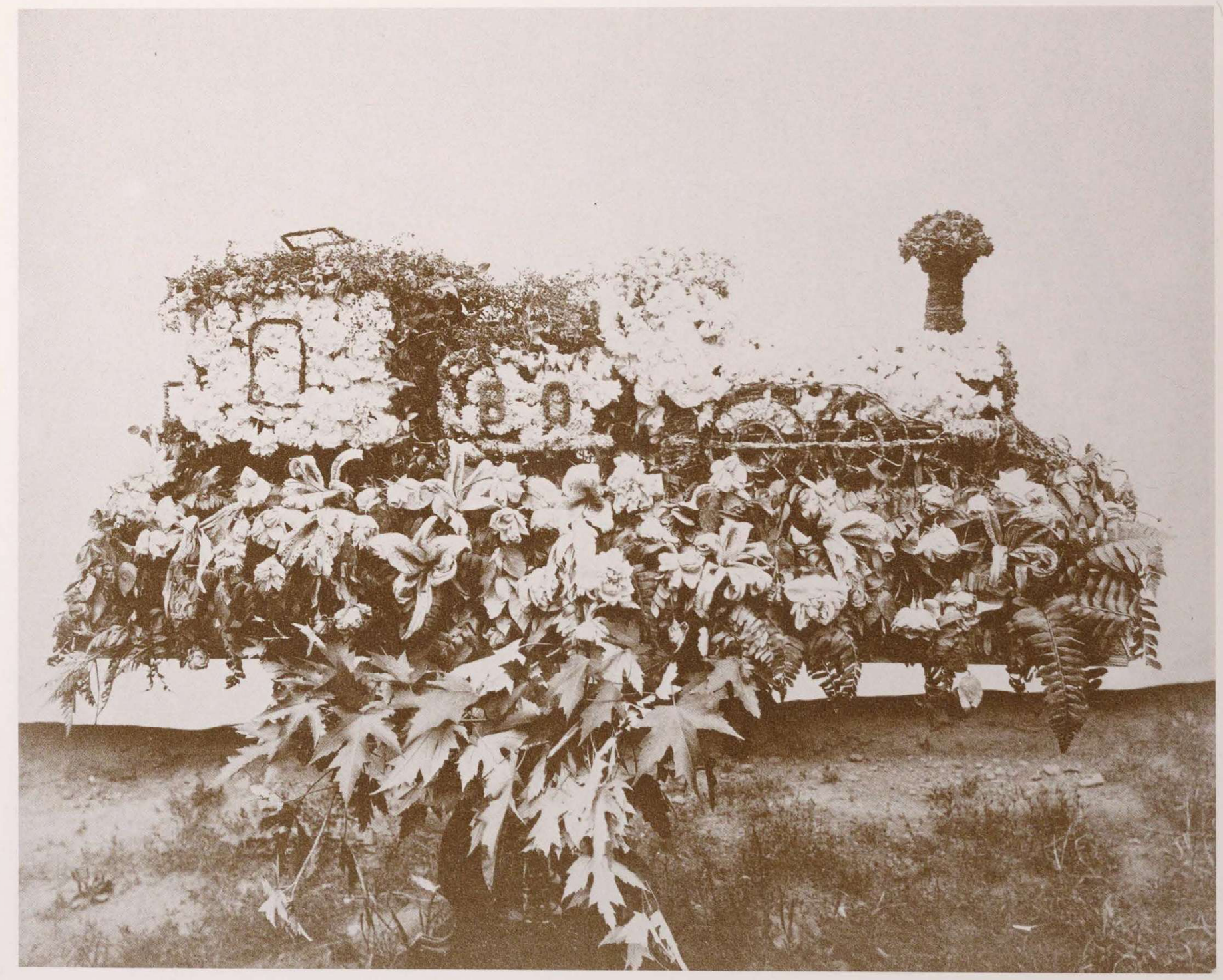

Figure 14 B\&O Railroad funeral wreath. U.S. View Company. 


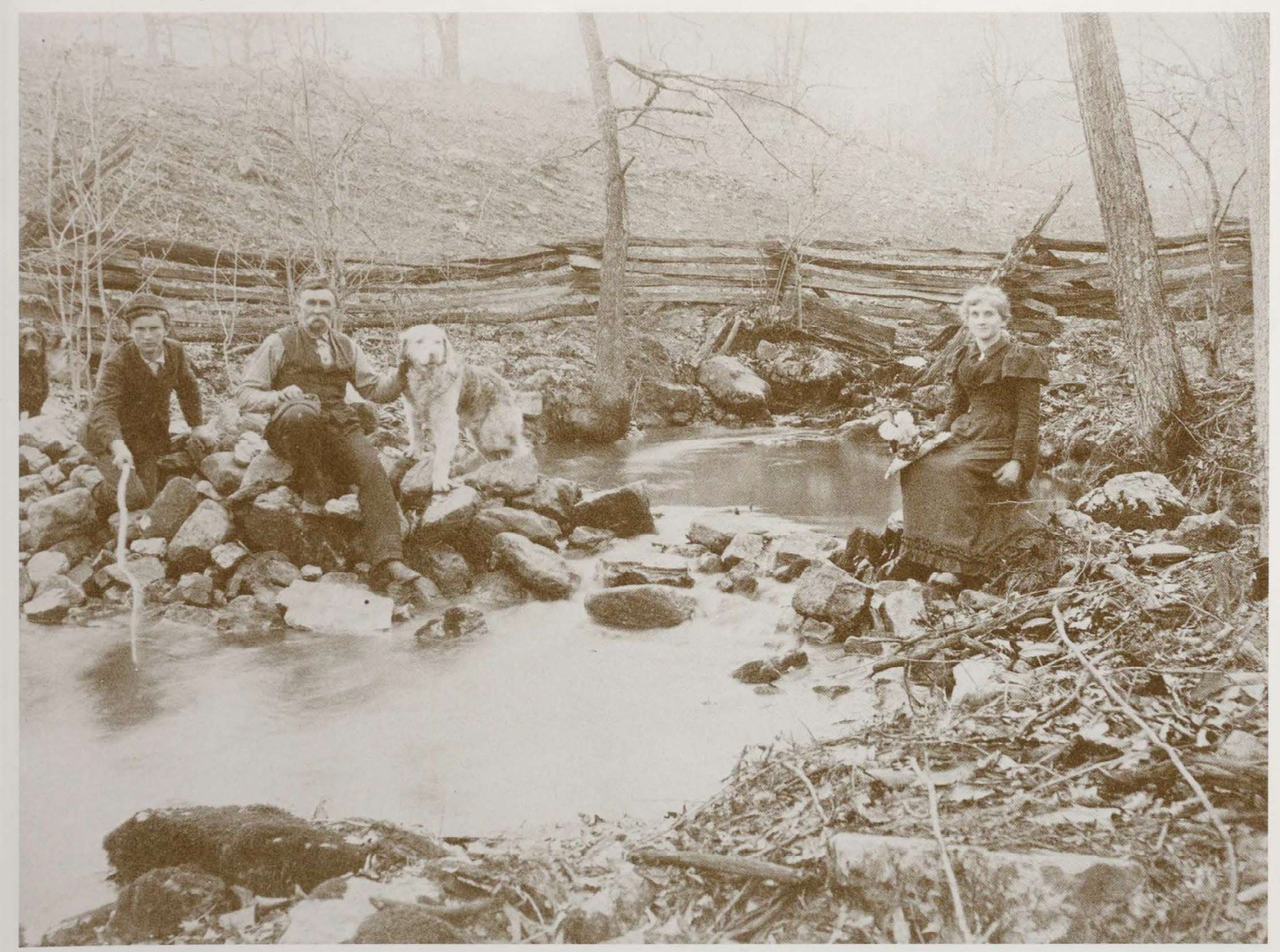

Figure 15 Unidentified family. U.S. View Company. 


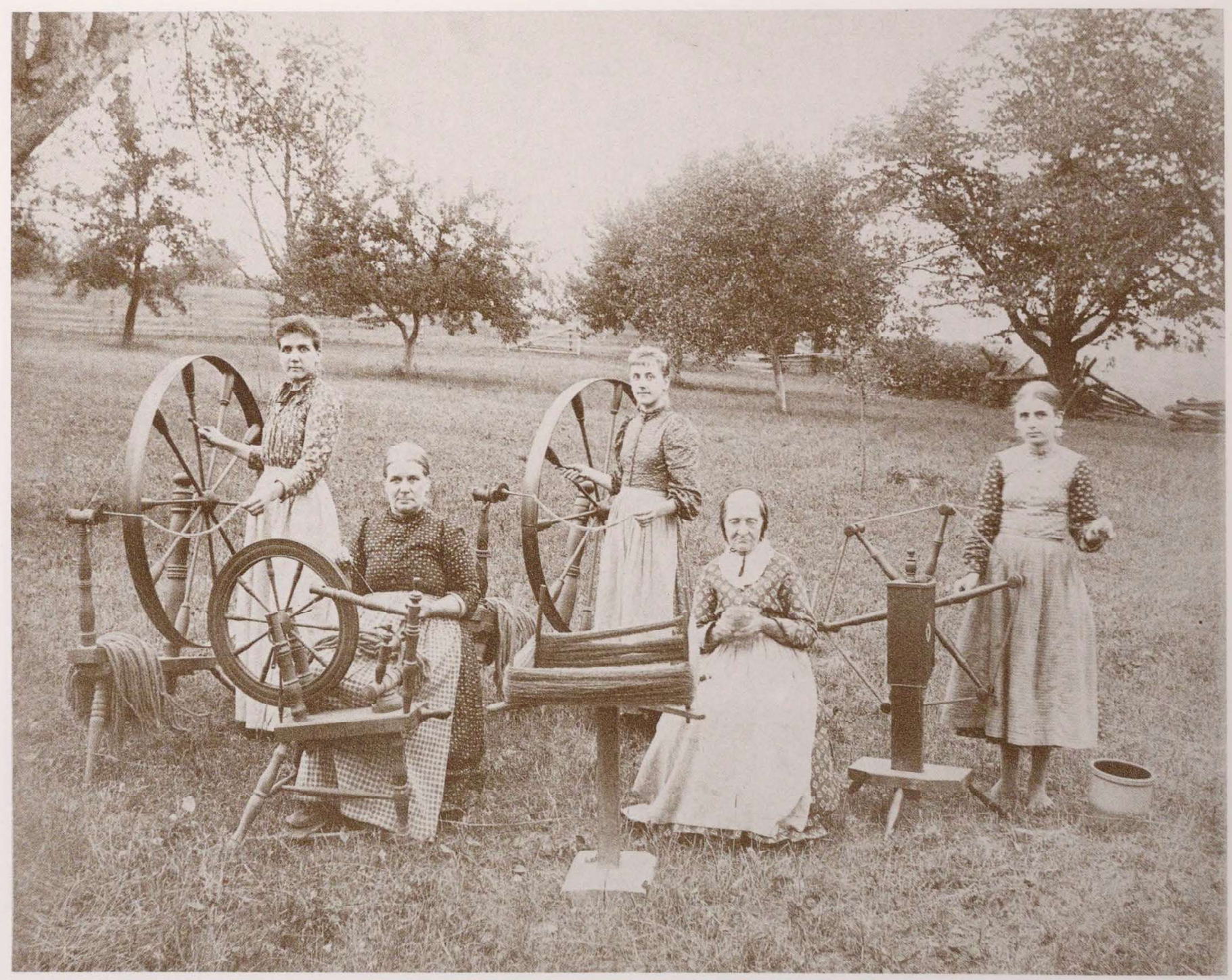

Figure 16 Unidentified group. U.S. View Company. 


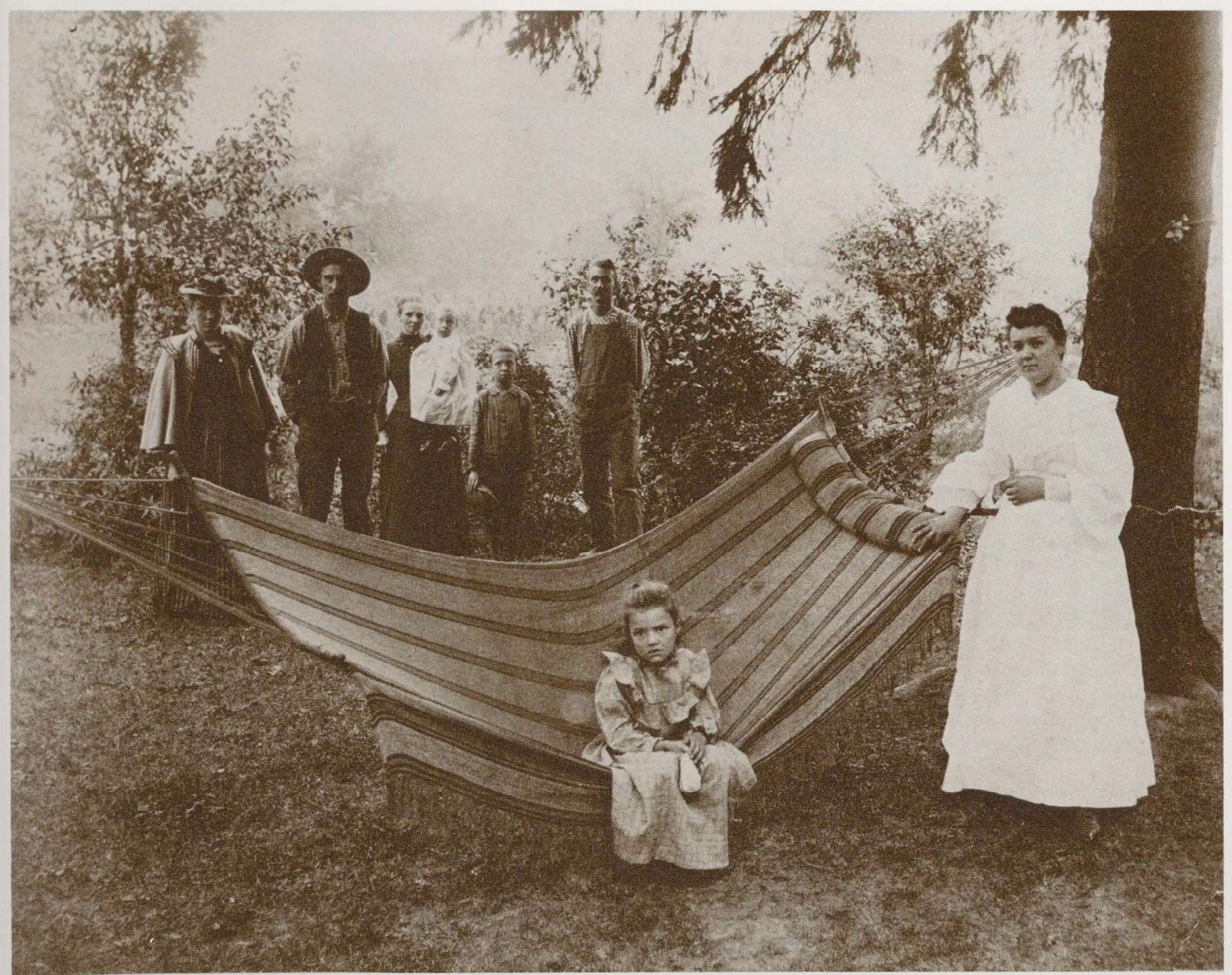

Figure 17 Unidentified group. U.S. View Company. 


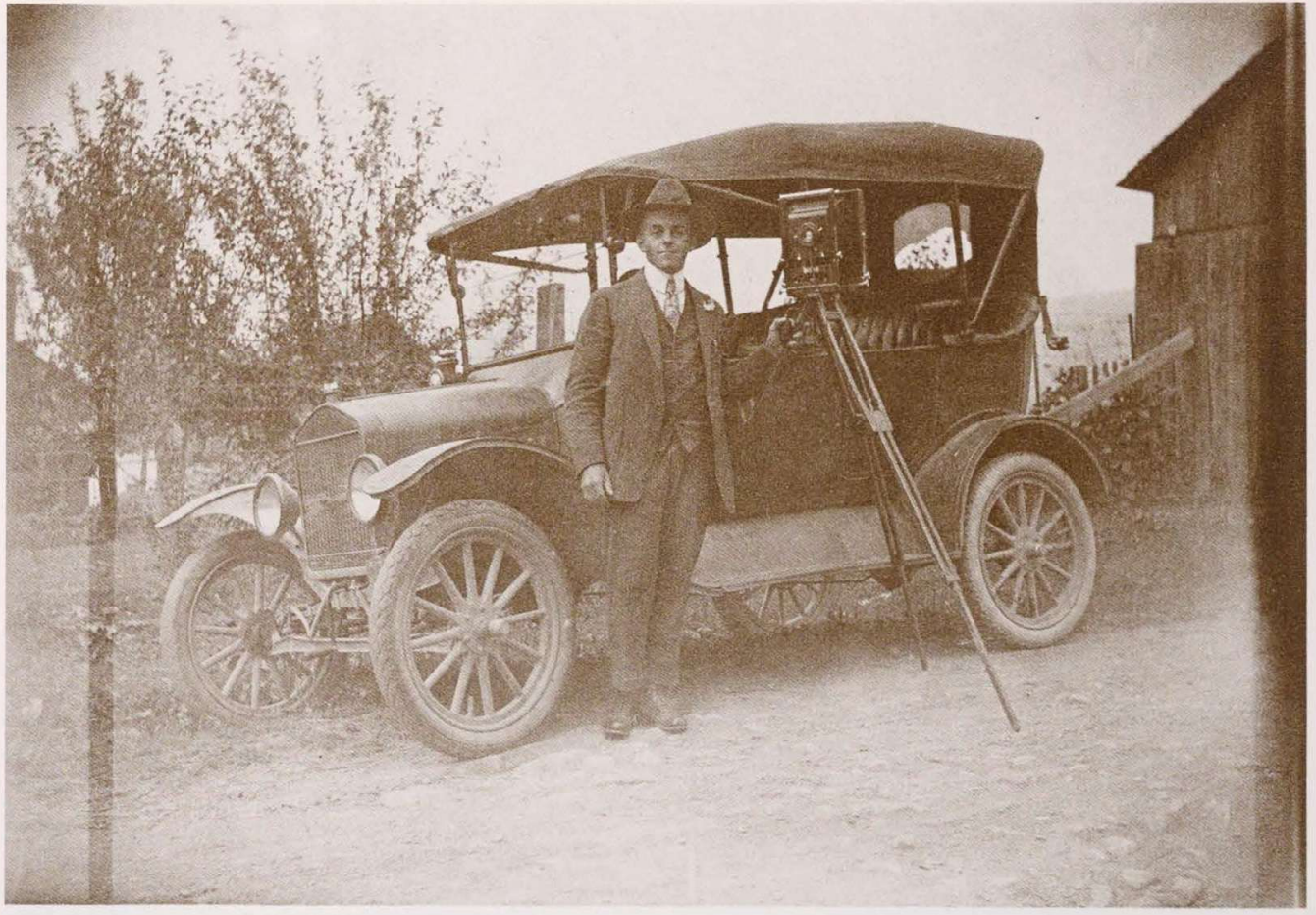

Figure 18 Postcard photographed by Harry Graybill, operator for the American Photo Company, Richfield, Pa.

\section{References}

- Ruby, Jay

1981 Seeing Through Pictures: The Anthropology of Photography Camera Lucida 3:20-33.

- Slavin, Neal

1976 When Two or More Are Gathered Together. New York: Farrar Straus and Giroux.

- Wright, Gwendolyn

1981 Building the Dream: A Social History of Art. New York: Pantheon. 